pipe begins to sound--but also set up vibrations in the metal of the pipe which may bear no relation to the fundamental note. The more rigid the material the stronger are these effects; weaker ones, such as the tin-lead alloys, damping them out. The results show clearly the sharper tones due to the use of copper and particularly the hardness and musically disturbing notes produced by zinc. Wooden pipes yield softer notes and are specially suited to some special stopped pipes and flutes, while lead-tin alloy is best for those stops required to give a full, soft note. Of the materials examined, the 70 per cent tin +30 per cent lead alloy is outstanding as the nearest approach to the ideal material for such use. Drs. Lottermoser and Meyer's results are summarized in No. 58 of Tin and Its Alloys (1963), published by the Tin Research Institute, and also in full in the February 1962 issue of Metall (p. 108).

\section{Chemical Analysis of Fruit Juices: Standardization of Methods}

The Scientific and Technical Commission of the International Federation of Fruit Juice Producers have set up a Sub-commission for the Standardization of the Chemical Analysis of Fruit Juices. Several European countries are represented on the Sub-commission and their recommendations have now been published (International Federation of Fruit Juice Producers. Analyses. Pp. 38. Wädenswil, Switzerland: Dr. Hans Lüthi, Sektion Getränkechemie und Biologie, Eidg. Versuchsanstalt für Obst-, Wien- und Gartenbau. 1962). Methods are described for the determination of specific gravity, alcohol, titratable acid, sugar, volatile and non-volatile acids and sulphur dioxide. In each case the dotails of the necessary apparatus, reagents and determination procedure are deseribed in separate English, German and French sections. A. useful feature is the inclusion of the degree of accuracy to which each result should be roported. In addition the general principle of each of the procedures is briefly indicated, but, as usual with standard methods, the interpretation of the results is not discussed. The publication is in loose-leaf form so that supplements can be added when nocossary. The introduction states: "This standardization of our chemical methods is very urgent, especially with regard to international negotiations".

\section{Survey of Hospital In-Patients in Britain}

THE full report on the Hospital In-Patient Enquiry for the Year 19.59 has recently been published by the Registrar General (H.M.S.O. $£ 17 s .6 d$.). The inquiry is based on forms completed by hospitals for every tenth patient discharged or died, the selection of patients being at random. The inquiry was originally begun in 1949; but until 1957 it was based on hospitals whose cooperation was voluntary. Sinee 1957 all non-psychiatric hospitals in England and Wales have boon included, though some cases, mainly private and staff pationts, havo koon oxcluded from the analysis. This consists of tables, showing the number of deaths and discharges (spells) and the associated rates by various characteristics, such as sox, ago, region, diagnostic group, and department of hospital in which the treatment took place. There is also a special and detailed analysis of maternity cases. The figures are oxtremely detailed, and defy any attempt at summarizing within a short space. They do, of course, relate to spells in hospital, rather than to individual cases, and no attempt has been made to uso the information about the occupation of the patients or the industry in which they worked which is collected on the forms. Many other possible cross-tabulations will no doubt occur to users of the material, and the foreword invites interested persons to inquire at the General Register Office for additional information which may be available.

\section{Tenth International Botanical Congress, Edinburgh}

THE tenth International Botanical Congress is to be held in Edinburgh during August 3-12, 1964. Some ten thousand preliminary circulars have been dispatched to botanists all over the world. The second Congress cireular, which gives details of the scientific programme and the full programme of botanical excursions, is due to be dis. patched in August or early September. Copies of the circular can be obtained from the Secretary (Executive Committee), Tenth International Botanical Congress, 5 Hope Park Squaro, Edinburgh 8.

\section{The Night Sky in September}

Futu moon oceurs on Sept. 3d. 19h. 34m. U.T. and new moon on Sept. $17 \mathrm{~d} .20 \mathrm{~h}$. $51 \mathrm{~m}$. The following conjunctions with the Moon occur: Sept. 2d. 05h., Saturn $1^{\circ} \mathrm{N}$.; Sept. 6d. 07h., Jupiter $4^{\circ}$ N.; Sept. 21d. 03h., Mars $5^{\circ}$ S.; Sept. $29 \mathrm{~d} .12 \mathrm{~h}$., Saturn $\mathrm{I}^{\circ} \mathrm{N}$. In addition to these conjunctions with the Moon, Mars is in conjunction with Spica on Sept. 1d. 00h., Mars being $2^{\circ} \mathrm{N}$. Mercury, Venus and Mars are too close to the Sun for easy observation. Jupiter rises at $20 \mathrm{~h} .00 \mathrm{~m} ., 19 \mathrm{~h} .00 \mathrm{~m}$. and $18 \mathrm{~h} .00 \mathrm{~m}$. on September 1, 15 and 30, respectively. It is in Pisces, its stellar magnitude is $\mathbf{- 2 . 4}$ and its distance from the Earth on September 15 is 375 million miles. Saturn sets at $3 \mathrm{~h} .20 \mathrm{~m}$., $2 \mathrm{~h} .20 \mathrm{~m}$. and $1 \mathrm{~h} .20 \mathrm{~m}$. at the beginning, middle and end of the month, respectively. It is in Capricornus, its stellar magnitude is +0.6 and its distance from the Earth on September 15 is 840 million miles. Occultations of stars brighter than magnitude 6 are as follows, observations being made at Greenwich: Sopt. 5d. 0h. 36.9m., 30 Psc. $(R)$; Sept. 7d. 22h. 49.3m., $\mu$ Cet. $(D)$; Sept. 7d. 23h. 48.7m., $\mu$ Cet. $(R)$; Sept. 26d. 20h. $45 \cdot 2 \mathrm{~m}$., 154 B. Sgr. $(D)$. $D$ and $R$ refer to disappearance and reappearance, respectively. The autumnal equinox occurs on Sept. 23d. 18h.

\section{University News :}

Belfast

THe following appointments to lectureships have been announced: Dr. R. M. Hobson (physics); Dr. M. A. Leonard (inorganic and analytical chemistry); Dr. P. J.S. Boaden (zoology); Dr. J. M. Dunbar (bacteriology). Mr. C. D. Kemp has been appointed to a senior lectureship in statistics.

Bristol

DR. F. G. A. Stone, reader in inorganic chemistry in Queen Mary College, London, has boon appointed to the chair of inorganic chemistry. Dr. J. M. Ziman, lecturer in physics, University of Cambridge, has been appointed to the chair of theoretical physics. The following appointments to lectureships have been announced: J. F. Harper (mathematics); Dr. G. M. Jarman (zoology); A. Koller (physics); Dr. K. Lederis (pharmacology); D. Lovelock (mathematics); Dr. J. MacMillan (organic chemistry); Dr. A. Simpson (aeronautical engineering); Dr. M. A. Sloigh (zoology).

Cambridge

Dr. L. Weiskrantz, of King's College, assistant director of research in experimental psychology, has been elected to a fellowship (Title $A$ ) of Churchill College as from October 1.

Cardiff

Dr. L. CRombre, at present reader in organic chemistry at King's College, London, has been appointed to the chair of organic chemistry at University College of South Wales and Monmouthshire.

East Anglia

Dr. R. T. JoY has been appointed lecturer in the School of Biological Sciences. 